\title{
Synergistic cytotoxic effect of genistein and doxorubicin on drug-resistant human breast cancer MCF-7/Adr cells
}

\author{
JIA-PENG XUE, GENG WANG, ZONG-BIN ZHAO, QUN WANG and YUN SHI
}

Department of Endocrine and Vascular Surgery, Taihe Hospital, Hubei Medical College, Shiyan, Hubei 442000, P.R. China

Received March 4, 2014; Accepted July 11, 2014

DOI: $10.3892 /$ or.2014.3365

\begin{abstract}
The molecular mechanisms underlying genisteinmediated reversal of chemoresistance remains unknown. In the present study, we investigated the molecular mechanisms by which genistein overcomes chemoresistance and its effect on doxorubicin-induced cytotoxicity. Consistent with previous reports, genistein combined with doxorubicin had a synergistic effect on MCF-7/Adr cells, and genistein reduced the chemoresistance of these cells. Genistein treatment increased the intracellular accumulation of doxorubicin but did not influence P-gp function. The combination of genistein and doxorubicin significantly induced cell cycle arrest and apoptosis. Genistein treatment strongly inhibited HER2/neu but not MDR-1 expression at both the mRNA and protein levels. Therefore, our results demonstrated that genistein combined with doxorubicin had a synergistic effect on MCF-7/Adr cells, and the mechanisms likely involve an increase in the intracellular accumulation of doxorubicin and suppression of HER2/neu expression.
\end{abstract}

\section{Introduction}

Breast cancer, a type of cancer originating from breast tissue, is a common cancer and the second leading cause of cancer-related mortality among women $(1,2)$. Although there has been a sustained decline in the mortality rates in recent decades due to development of increasingly effective adjuvant medical treatments, relapse after the first 5 years is frequent and is a major contributor to breast cancer mortality (3-5). The major reason for relapse is chemoresistance acquired during the chemotherapeutic process (6-8). Therefore, overcoming acquired chemoresistance is critically important to reducing the rate of relapse and improving prognosis.

Doxorubicin, also known as adriamycin, is an anthracycline antibiotic that functions by intercalating DNA (9). It is commonly used in the treatment of a wide range of cancers,

Correspondence to: Dr Geng Wang, Department of Endocrine and Vascular Surgery, Taihe Hospital, Hubei Medical College, Shiyan, Hubei 442000, P.R. China

E-mail:wg129@sina.com

Key words: genistein, MCF-7/Adr, reversal of multidrug resistance, doxorubicin including breast cancer, hematological malignancies, soft tissue sarcomas and many types of carcinoma (10-12). However, a long duration of doxorubicin treatment often causes cancer cell resistance to treatment and has the serious adverse effect of life-threatening heart damage $(13,14)$. Elucidating the molecular mechanisms that underlie chemoresistance and overcoming established chemoresistance to doxorubicin are clinically relevant challenges in breast cancer treatment.

Genistein, first isolated from the dyer's broom in 1899 , is a phytoestrogen and belongs to the category of isoflavones. Various studies have found that genistein has inhibitory effects on many types of cancers, including breast cancer $(15,16)$. More importantly, several studies have shown that genistein can enhance chemotherapeutic efficacy and overcome chemoresistance in breast cancer (17-19). However, the molecular mechanisms underlying genistein-mediated reversal of chemoresistance are still largely unknown.

\section{Materials and methods}

Materials and equipment. The human breast cancer cell line MCF-7 and resistant derivative cell line MCF-7/Adr were gifted by the Department of Surgery, Wuhan Union Hospital, Hubei, China. Sensitive human breast cancer MCF-7/s cells were obtained from ATCC (USA). The MCF-7/adr cells (Michigan Cancer Foundation-7/adriamycin resistant) were kindly provided by Dr. Huang Tao (University of Science and Technology of Xiehe Hospital at Huazhong Surgery Laboratory Center, Wuhan, Hubei). The cell line is derived from the parental drug-sensitive MCF-7 cells by stepwise selection with Dox. To maintain the drug-resistant phenotype, the cells were cultured in the presence of $1 \mu \mathrm{g} / \mathrm{ml}$ Dox in RPMI-1640 culture medium supplemented with $10 \%$ heat-inactivated fetal bovine serum (Invitrogen), $10 \mathrm{mM}$ glutamine, and antibiotics (100 U/ml penicillin and $100 \mu \mathrm{g} / \mathrm{ml}$ streptomycin). Cells were maintained at $37^{\circ} \mathrm{C}$ in $5 \% \mathrm{CO}_{2} / 95 \%$ air $(20-22)$.

Genistein and rhodamine (Rh123) were obtained from Sigma-Aldrich (USA). Doxorubicin hydrochloride was purchased from Shanghai Biological Engineering Co., Ltd. (China). Oligo(dt) was synthesized by Shanghai Biological Engineering Co. Taq PCR MasterMix was purchased from Tiangen (China). Primers were synthesized by Shanghai Biological Engineering Co. Anti-human permeability glycoprotein (P-gp) monoclonal antibody was purchased from Abcam (USA). Anti-c-erbB2 [human epidermal growth factor 
receptor $2(\mathrm{Her} 2 / \mathrm{Neu})]$ polyclonal antibody was purchased from Dako Corp. (USA). Anti-mouse IgG-horseradish peroxidase (HRP) and anti-rabbit IgG-HRP were purchased from Beijing Ding National Biotechnology Co. (China). A Coulter DNA PREP ${ }^{\mathrm{TM}}$ reagents kit was purchased from BeckmanCoulter (USA). An Annexin V-FITC apoptosis detection kit was purchased from Shanghai Yan-Bin Chemical Technology (China). The F-7000 fluorescence spectrometer was purchased from Hitachi (Japan), and the Hitachi UV spectrophotometer was from Eppendorf (Germany).

Cells and culture. Cells were cultured in RPMI-1640 culture medium with $10 \%$ fetal calf serum at $37^{\circ} \mathrm{C}$ with $5 \% \mathrm{CO}_{2}$. Cells were trypsinized with $0.25 \%$ trypsin and passed every 2 or 3 days. MCF-7/Adr cells were maintained in medium supplemented with doxorubicin $(1.0 \mu \mathrm{g} / \mathrm{ml})$ for two weeks. Cells were diluted from $5 \times 10^{4}$ to $5 \times 10^{5} / \mathrm{ml}$ for use in the experiments.

Preparation of genistein. The purity of genistein was greater than $98 \%$. Twenty-five milligrams of genistein was dissolved in $1 \mathrm{ml}$ dimethylsulfoxide (DMSO) and stored at $4^{\circ} \mathrm{C}$. Before use, genistein was diluted in culture medium to the required concentration, with the final percentage of DMSO $<0.2 \%$. Twenty-five milligrams of doxorubicin was dissolved in $10 \mathrm{ml}$ saline and stored at $20^{\circ} \mathrm{C}$. For experiments, doxorubicin was serially diluted to final concentrations of $0.1,1,10$ and $100 \mu \mathrm{M}$.

MTT assay. MCF-7/Adr cells in the logarithmic growth phase were seeded in 96-well culture plates. To each well, we added $30 \mu \mathrm{mol} / 1$ genistein and $0.07,0.7,7$ or $70 \mu \mathrm{M}$ doxorubicin, in a final volume of $200 \mu \mathrm{l}$ ( $\mathrm{n}=8$ for each concentration). Wells with medium only (no cells) were used to measure the background, and seeded wells given untreated medium served as the controls. Forty-eight hours after treatment, MTT was added to measure proliferation. Q-value was calculated by the formula of Guinness (17-19). IC $_{50}$ and the reversal fold were also calculated. The reversal fold $=\mathrm{IC}_{50}$ (chemotherapy drugs)/ $/ \mathrm{IC}_{50}$ (genistein).

Fluorospectrophotometry. Quantification of doxorubicin concentrations was carried out using a standard curve. The standard curve was established using standard solutions of different doxorubicin concentrations $(0,0.01,0.05,0.25,1.25$, 6.25 and $31.25 \mu \mathrm{M})$. Cell culture medium was added to yield final genistein concentrations of 7, 15, 30, 60 and $120 \mu \mathrm{mol} / \mathrm{l}$, and $0.7,7$ and $70 \mu \mathrm{M}$ doxorubicin. After experimental culture, the supernatants were collected and centrifuged, and fluorescence intensity was measured. The concentration of doxorubicin in the supernatant was calculated according to the standard curve.

Analyses of cell cycle and apoptosis by flow cytometry. MCF-7/Adr cells in the logarithmic growth phase were seeded in 24-well plates. The cells were divided into following groups: control group (culture medium), doxorubicin groups (10 or $100 \mu \mathrm{M}$ ), genistein groups (30 or $60 \mu \mathrm{mol} / \mathrm{l}$ ), low-dose combination group ( $1 \mu \mathrm{M}$ doxorubicin $+30 \mu \mathrm{mol} / 1$ genistein), and high-dose combination group $(10 \mu \mathrm{M}$ doxorubicin $+60 \mu \mathrm{mol} / 1$ genistein). The final concentration of DMSO was $0.1 \%$. Then cells were harvested and washed twice with cold PBS. Cells were suspended in cold $70 \%$ ethanol and fixed overnight at $-20^{\circ} \mathrm{C}$. Fixed cells were centrifuged, resuspended in resuspension buffer, and $100 \mu \mathrm{l}$ propidium iodide (PI; $50 \mu \mathrm{g} / \mathrm{ml}$ ) was added and incubated for $30 \mathrm{~min}$ at $4^{\circ} \mathrm{C}$ for staining. A 200- $\mu 1$ sample was transferred to an injection tube, along with $100 \mu 1$ Coulter DNA-PREP reagents kit. After 2 min of mixing, $1 \mathrm{ml}$ Coulter DNA-PREP reagents kit stain was added and the solution was mixed. PI single staining was used to assess cell cycle via flow cytometry. PI and Annexin V-FITC double staining was used to measure apoptosis. To measure Rh123, a fluorescent substrate of P-gp, a cell suspension was added to $2 \mathrm{mg} / \mathrm{l} \mathrm{Rh} 123$ or Rh123 + different concentrations of genistein and incubated at $37^{\circ} \mathrm{C}$ for $45 \mathrm{~min}$. Cells were washed twice with cold PBS, and Rh123 concentrations were measured by flow cytometry.

RT-PCR. MCF-7/Adr cells in the logarithmic growth phase were seeded in 6-well plates and divided into the following groups: control, doxorubicin (1 or $10 \mu \mathrm{M})$, genistein $(15,30$ or $60 \mu \mathrm{mol} / \mathrm{l})$. After $48 \mathrm{~h}$ of treatment, cells were harvested and total-RNA was extracted. The A260:A280 ratio was $\geq 1.8$. RT-PCR was performed according to the two-step RT-PCR amplification kit instructions. The primers were as follows: mdr-1 forward, 5'-CCCATCATTGCAATAGCAGG-3' and reverse, 5'-GTTCAAACTTCTGCTCCTCA-3'; Her2/neu forward, 5'-GCCCTCATCCACCATAACACC-3' and reverse, 5'-CATTCCTCCACGCACTCCTG-3'; $\beta$-actin forward, 5'-AGCGAGCATCCCCCAAAGTT-3' and reverse, 5'-GGG CACGAAGGCTCATCATT-3'. The PCR product of mdr-1 is $157 \mathrm{bp}$; the PCR product of Her2/neu is $220 \mathrm{bp}$; and the PCR product of control $\beta$-actin is $200 \mathrm{bp}$. PCR conditions were as follows: $94^{\circ} \mathrm{C}$ denaturation for $30 \mathrm{sec}, 57^{\circ} \mathrm{C}$ refolding for $30 \mathrm{sec}$, and $72^{\circ} \mathrm{C}$ extension for $30 \mathrm{sec}$, for a total of 30 cycles.

Western blot analysis. Cells were washed with cold PBS and lysed with protein lysis buffer for $30 \mathrm{~min}$. Cell lysates were centrifuged at $12,000 \mathrm{x} \mathrm{g}$ at $4^{\circ} \mathrm{C}$ for $15 \mathrm{~min}$. After centrifugation, supernatants were considered as total protein extract. The total amount of protein for loading was adjusted using the measured protein concentration. Six microliters of 5X sample buffer was added to each sample for a final volume of $30 \mu \mathrm{l}$. Samples were boiled at $100^{\circ} \mathrm{C}$ for $5 \mathrm{~min}$ (protein denaturation) and subjected to electrophoresis at $4^{\circ} \mathrm{C}$. Proteins in the gel were transferred to a polyvinylidene fluoride membrane and blotted with anti-human P-gp antibody (diluted 1:20 in blocking solution) and the anti-c-erbB2 antibody (1:500) overnight at $4^{\circ} \mathrm{C}$. HRP-conjugated secondary antibodies were added for $2 \mathrm{~h}$.

Statistical methods. SPSS 17.0 software was used for variance and regression analyses and pairwise comparisons Q-test. Data are presented as means \pm standard deviation (SD). Comparison between groups was performed via t-test. $\mathrm{P}<0.05$ was considered to indicate a statistically significant difference.

\section{Results}

MCF-7/Adr cells are resistant to doxorubicin-induced cell death. It is known that MCF-7/Adr cells are resistant to doxorubicin once the cell line is established. To confirm that MCF-7/Adr cells do have this biological feature, we compared 


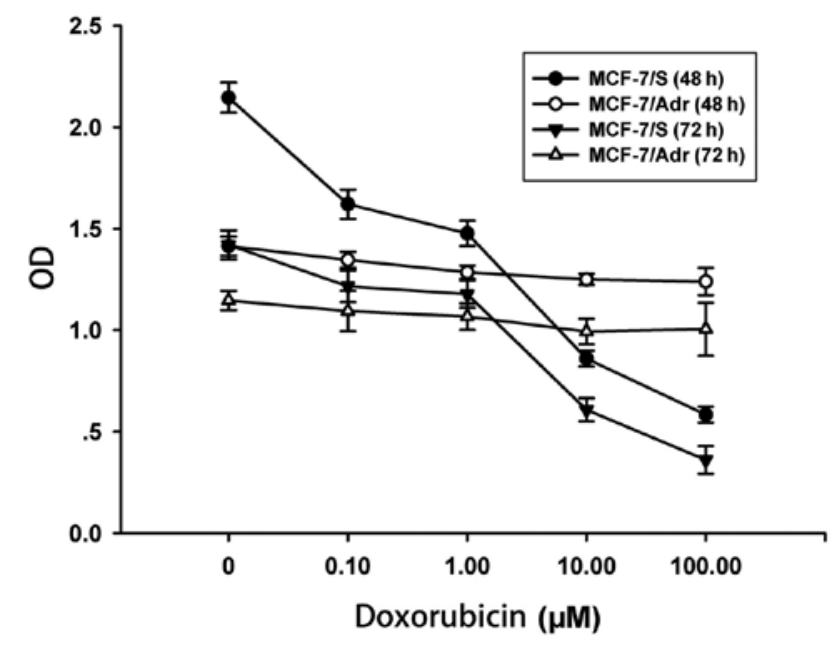

Figure 1. Chemoresistance of MCF-7/Adr but not MCF-7/S cells to doxorubicin. Cytotoxic effects of doxorubicin on MCF-7/Adr and MCF-7/S cells are represented by mean OD values $\pm \mathrm{SD}(\mathrm{n}=8)$. DO, optical density that reflects the number of cells. ${ }^{*} \mathrm{P}<0.05$, comparison between MCF7/Adr and MCF-7/S cells.

Table I. Genistein enhances the cytotoxic effect of doxorubicin in MCF-7/Adr cells (mean $\pm \mathrm{SD}, \mathrm{n}=8$ ).

\begin{tabular}{lccc}
\hline & \multicolumn{3}{c}{ Gen dose $(30 \mu \mathrm{mol} / \mathrm{l})$} \\
\cline { 2 - 4 } Dox dose $(\mu \mathrm{M})$ & OD & IR $(\%)$ & Q-value \\
\hline Control & $0.676 \pm 0.035$ & - & - \\
0.07 & $0.534 \pm 0.062^{\mathrm{a}}$ & 20.91 & 1.42 \\
0.7 & $0.470 \pm 0.063^{\mathrm{a}}$ & 30.40 & 1.67 \\
7.0 & $0.472 \pm 0.051^{\mathrm{a}}$ & 30.13 & 1.83 \\
70 & $0.457 \pm 0.080^{\mathrm{a}}$ & 47.17 & 2.09 \\
$\mathrm{IC}_{50}$ & \multicolumn{3}{c}{73.89} \\
Fold & \multicolumn{3}{c}{7.53} \\
\hline
\end{tabular}

${ }^{\mathrm{a}} \mathrm{P}<0.01$, compared to the control group. ${ }^{\mathrm{b}} \mathrm{P}<0.05$ vs. Dox or Gen. Dox, doxorubicin; Gen, genistein.

the sensitivity of MCF-7/S and MCF-7/Adr cells. As shown in Fig. 1, doxorubicin inhibited the cell proliferation of MCF-7/S cells in a dose- and time-dependent manner; however, doxorubicin had no inhibitory effect on MCF-7/Adr cells. In MCF-7/Adr cells, the $\mathrm{IC}_{50}$ for a 48 -h treatment was $117.15 \mu \mathrm{M}$ (4.75 \pm 0.04 to $556.21 \pm 51.35 \mu \mathrm{M}$ ), whereas the $\mathrm{IC}_{50}$ for a $72-\mathrm{h}$ treatment was $54.42 \mu \mathrm{M}(8.95 \pm 0.08$ to $486.90 \pm 45.33 \mu \mathrm{M})$. Taken together, our results confirmed that the MCF-7/Adr cells were resistant to doxorubicin.

Genistein enhances the cytotoxic effect of doxorubicin in $M C F-7 / A d r$ cells. Several studies have shown that genistein can enhance the cytotoxic effects of doxorubicin and reduce the chemoresistance of tumor cells (17-19). To test this observation, we treated MCF-7/Adr cells with genistein $(30 \mu \mathrm{mol} / \mathrm{l})$ along with increasing doses of doxorubicin. We found that genistein had a synergistic effect with doxorubicin at all tested doses $(\mathrm{Q}>1.15$; Table I). The inhibitory effect of doxorubicin
Table II. Effect of genistein on the intracellular accumulation of doxorubicin in MCF-7/Adr cells $(\mathrm{n}=8)$.

\begin{tabular}{lccc}
\hline & \multicolumn{3}{c}{ Dox $(\mu \mathrm{M})$} \\
\cline { 2 - 4 } Gen $(\mu \mathrm{mol} / \mathrm{l})$ & 0.7 & 7 & 70 \\
\hline 0 & 0.16 & $0.20^{\mathrm{a}}$ & $0.22^{\mathrm{a}}$ \\
7 & 0.45 & 0.71 & 0.99 \\
15 & 0.79 & 0.95 & 1.21 \\
30 & $0.85^{\mathrm{b}}$ & $2.32^{\mathrm{c}}$ & $2.66^{\mathrm{c}}$ \\
60 & $1.73^{\mathrm{c}}$ & $3.59^{\mathrm{c}}$ & $4.55^{\mathrm{c}}$ \\
120 & $2.04^{\mathrm{c}}$ & $4.05^{\mathrm{c}}$ & $4.92^{\mathrm{c}}$ \\
\hline
\end{tabular}

${ }^{\mathrm{a}} \mathrm{P}>0.05$ vs. $0.7 \mu \mathrm{M}$ Dox; ${ }^{\mathrm{b}} \mathrm{P}<0.05$ vs. 0 and $7 \mu \mathrm{mol} / 1 \mathrm{Gen} ;{ }^{\mathrm{c}} \mathrm{P}<0.01$ vs. 0,7 and $15 \mu \mathrm{mol} / 1$ Gen. Dox, doxorubicin; Gen, genistein.

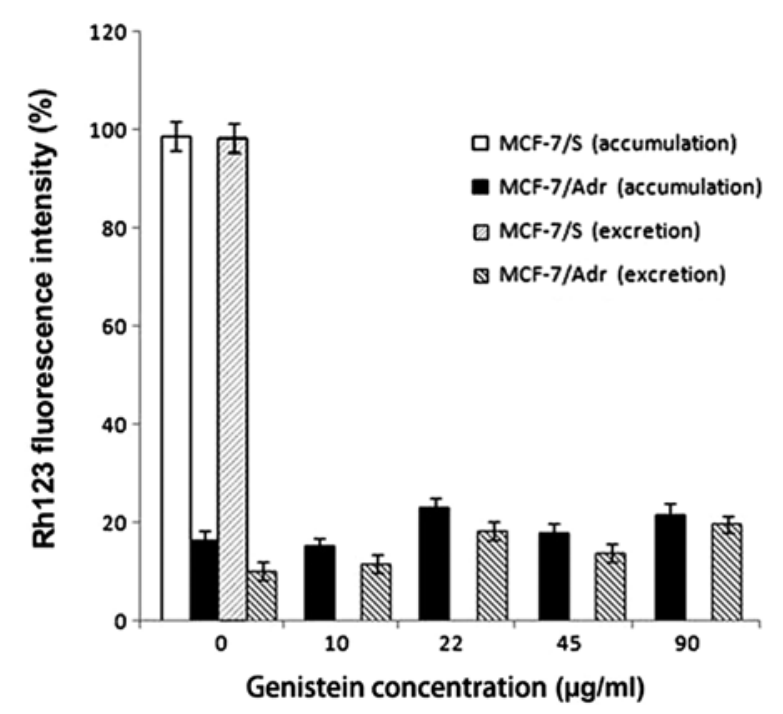

Figure 2. Genistein has no effect on the intracellular accumulation of Rh123. The concentration of Rh123 is represented by fluorescent intensity. Cells were incubated with different concentrations of genistein and Rh123 for $45 \mathrm{~min}$. Excretion of Rh123 was measured via fluorescent intensity of the culture media. Open bars represent the values of Rh123 measured in MCF-7/S cells. Black bars represent the values of Rh123 measured in MCF-7/Adr cells.

and genistein was significantly greater than that of the control and doxorubicin alone $(\mathrm{P}<0.01$; Table $\mathrm{I})$.

Genistein increases the intracellular accumulation of doxorubicin. Our results revealed that genistein enhanced the cytotoxic effect of doxorubicin. To better understand the molecular mechanism of this observation, we investigated whether genistein increases the intracellular accumulation of doxorubicin in MCF-7/Adr cells. The intracellular accumulation of doxorubicin was estimated by the formula $y=152.55+99.496 x, R^{2}=0.954$. As presented in Table II, genistein significantly increased the intracellular accumulation of doxorubicin $(\mathrm{P}<0.01)$. In the MCF-7/Adr cells, increased concentration of doxorubicin alone did not significantly upregulate the intracellular accumulation of doxorubicin, and the maximal intracellular loading of doxorubicin was extremely 
Table III. Effect of genistein on doxorubicin-induced MCF-7/Adr cell cycle arrest.

\begin{tabular}{|c|c|c|c|c|c|c|c|}
\hline \multirow[b]{2}{*}{ Group } & \multirow[b]{2}{*}{$\mathrm{n}$} & \multicolumn{3}{|c|}{$48 \mathrm{~h}$} & \multicolumn{3}{|c|}{$72 \mathrm{~h}$} \\
\hline & & $\mathrm{G}_{1}$ & $\mathrm{~S}$ & $\mathrm{G}_{2} / \mathrm{M}$ & $\mathrm{G}_{1}$ & $\mathrm{~S}$ & $\mathrm{G}_{2} / \mathrm{M}$ \\
\hline Control & 3 & 60.9 & 17.7 & 21.4 & 58.3 & 18.3 & 23.3 \\
\hline $30 \mu \mathrm{mol} / \mathrm{l} \mathrm{Gen}$ & 3 & 43.8 & 23.8 & $32.3^{\mathrm{a}}$ & 30.3 & 23.9 & $45.8^{\mathrm{a}}$ \\
\hline $60 \mu \mathrm{mol} / \mathrm{l} \mathrm{Gen}$ & 3 & 34.4 & $61.9^{\mathrm{a}}$ & 3.8 & 25.3 & 24.5 & $50.1^{\mathrm{a}}$ \\
\hline $30 \mu \mathrm{mol} / / \mathrm{Gen}+1 \mu \mathrm{M}$ Dox & 3 & 58.1 & 14.3 & $27.6^{\mathrm{a}}$ & 53.3 & 16.2 & $30.5^{\mathrm{a}}$ \\
\hline $60 \mu \mathrm{mol} / \mathrm{l} \mathrm{Gen}+10 \mu \mathrm{M}$ Dox & 3 & 32.3 & 34.8 & $32.9^{\mathrm{a}, \mathrm{c}}$ & 44.7 & 14.8 & $40.5^{\mathrm{a}, \mathrm{b}, \mathrm{c}}$ \\
\hline
\end{tabular}

${ }^{\mathrm{a}} \mathrm{P}<0.01$ vs. control; ${ }^{\mathrm{b}} \mathrm{P}<0.05$ vs. $48 \mathrm{~h}$; ${ }^{\mathrm{C}} \mathrm{P}<0.05$ vs. $30 \mu \mathrm{mol} / \mathrm{l} \mathrm{Gen}+1 \mu \mathrm{M}$ Dox. Dox, doxorubicin; Gen, genistein.
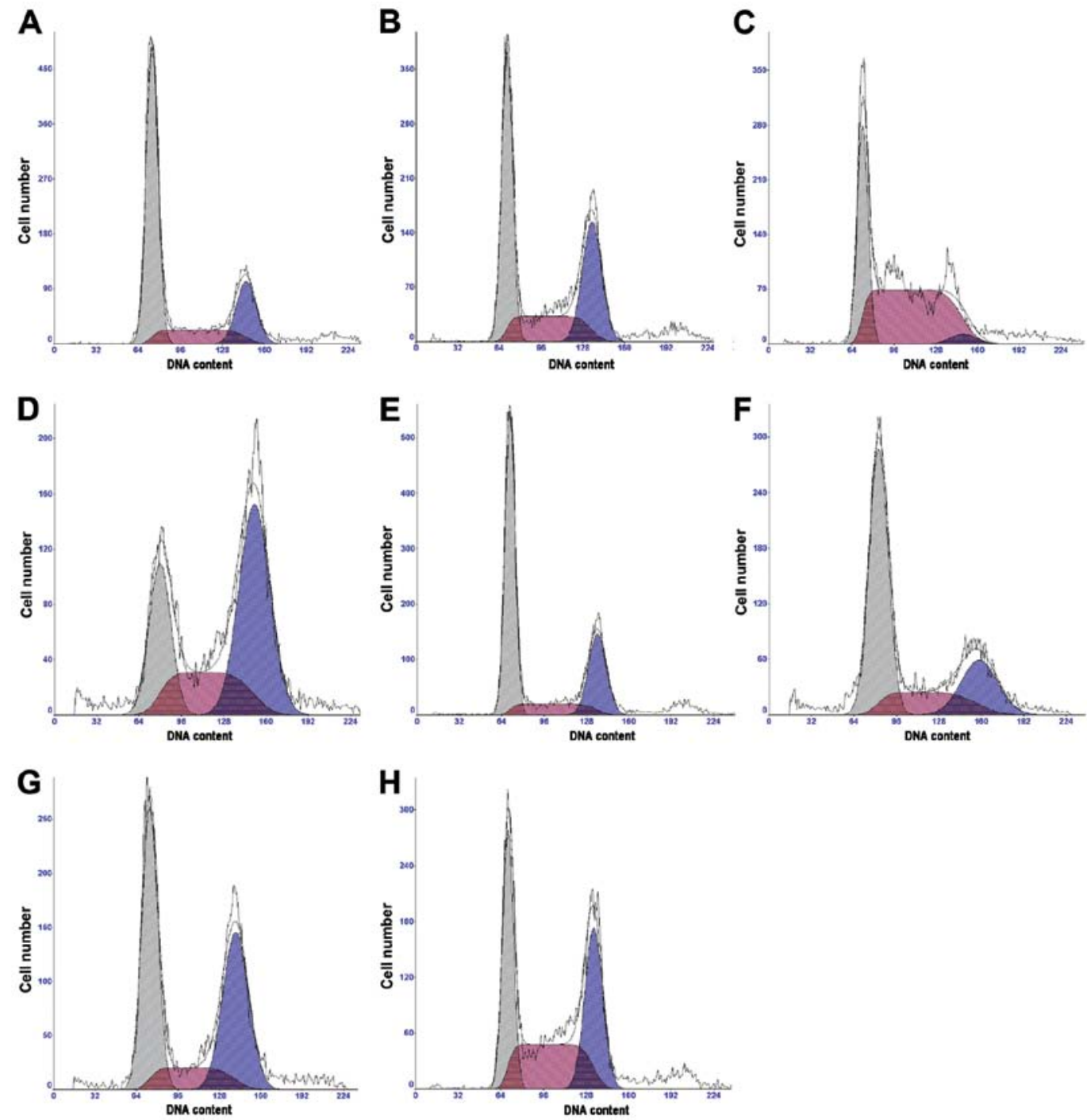

Figure 3. Effect of genistein on doxorubicin-induced cell cycle arrest analyzed by flow cytometry. The y-axis represents cell number. (A) Control, (B) $30 \mu$ mol/1 genistein (48 h), (C) $60 \mu \mathrm{mol} / 1$ genistein (48 h), (D) $60 \mu \mathrm{mol} / 1$ genistein (72 h), (E) $30 \mu \mathrm{mol} / 1$ genistein $+1 \mu \mathrm{M}$ doxorubicin (48 h), (F) $30 \mu \mathrm{mol} / 1$ genistein $+1 \mu \mathrm{M}$ doxorubicin $(72 \mathrm{~h}),(\mathrm{G}) 60 \mu \mathrm{mol} / 1$ genistein $+10 \mu \mathrm{M}$ doxorubicin $(48 \mathrm{~h})$ and $(\mathrm{H}) 60 \mu \mathrm{mol} / 1$ genistein $+10 \mu \mathrm{M}$ doxorubicin $(72 \mathrm{~h})$.

limited in the doxorubicin alone group (Table II). However, genistein treatment significantly increased the intracellular accumulation of doxorubicin in a dose-dependent manner. More importantly, the maximal loading of doxorubicin was greatly increased with genistein treatment (Table II).
Genistein has no effect on the intracellular accumulation or excretion of Rh123. To further understand the mechanism underlying doxorubicin accumulation in MCF-7/Adr cells, we tested the effect of genistein on the intracellular accumulation of Rh123, a fluorescent substrate of P-gp. Rh123 is transported 

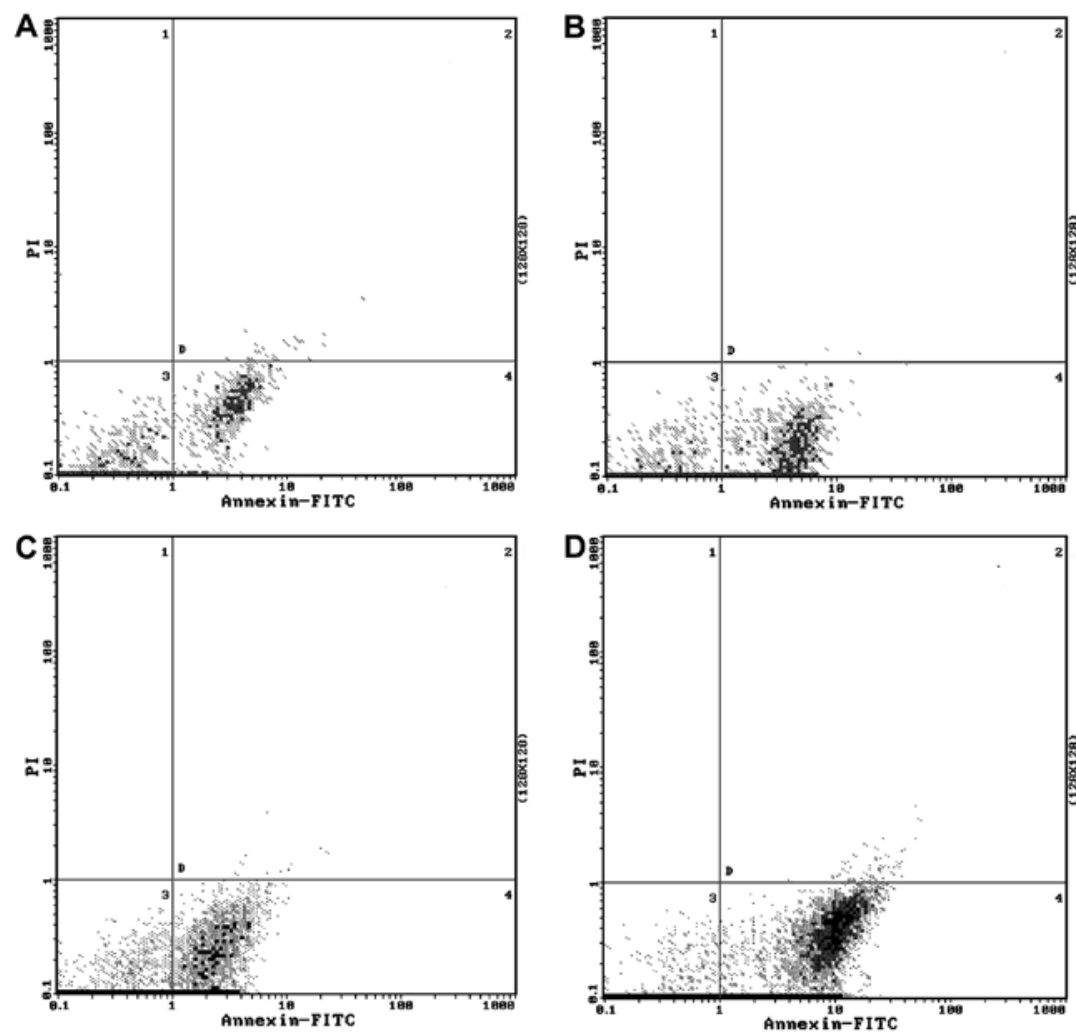

Figure 4. The effect of genistein on doxorubicin-induced apoptosis. (A) Control, (B) $10 \mu \mathrm{M}$ doxorubicin, (C) $60 \mu \mathrm{mol} / 1 \mathrm{genistein}$, (D) $60 \mu \mathrm{mol} / 1 \mathrm{genistein}+$ $10 \mu \mathrm{M}$ doxorubicin.

Table IV. Effect of genistein on doxorubicin-induced apoptosis

\begin{tabular}{lllc}
\hline & & \multicolumn{2}{c}{ Apoptosis rate (\%) } \\
\cline { 3 - 4 } Group & $\mathrm{n}$ & $\begin{array}{c}\text { Annexin (+) } \\
\text { PI (-) }\end{array}$ & $\begin{array}{c}\text { Annexin (+) } \\
\text { PI (+) }\end{array}$ \\
\hline Control & 3 & $5.92 \pm 0.22$ & $0.24 \pm 0.02$ \\
Dox $(10 \mu \mathrm{M})$ & 3 & $13.8 \pm 0.85$ & $0.02 \pm 0.01$ \\
Gen $(\mu \mathrm{mol} / 1)$ & 3 & $26.0 \pm 0.99^{\mathrm{a}}$ & $0.11 \pm 0.01$ \\
Gen $(60 \mu \mathrm{mol} / 1$ & 3 & $35.8 \pm 1.57^{\mathrm{a}, \mathrm{b}}$ & $0.57 \pm 0.04$ \\
$+\operatorname{Dox}(10 \mu \mathrm{M})$ & & & \\
\hline
\end{tabular}

${ }^{\mathrm{a}} \mathrm{P}<0.01$ vs. control; ${ }^{\mathrm{b}} \mathrm{P}<0.05$ vs. Dox or Gen. Dox, doxorubicin; Gen, genistein.

by P-gp and therefore can be used as a measure of drug extrusion by the plasma membrane (17-19). The intracellular accumulation assay showed that genistein had no effect on the intracellular accumulation of Rh123 (Fig. 2). Assays of Rh123 excretion by MCF7/S and MCF7/Adr cells also showed that genistein had no effect on the excretion of Rh123 (Fig. 2). These results suggest that genistein specifically affects the intracellular accumulation of doxorubicin but not that of Rh123.

Genistein increases doxorubicin-induced cell cycle arrest. Doxorubicin intercalates into DNA and induces cell cycle arrest.
We tested whether genistein increases doxorubicin-induced cell cycle arrest. Compared to the control, both genistein and doxorubicin significantly induced MCF-7/Adr cell cycle arrest at the $\mathrm{G} 2 / \mathrm{M}$ phase $(\mathrm{P}<0.01$; Table III and Fig. 3). Genistein treatment at $60 \mu \mathrm{mol} / 1$ for $48 \mathrm{~h}$ and $72 \mathrm{~h}$ resulted in decreased percentages of cells in the $\mathrm{G} 1$ and $\mathrm{G} 2 / \mathrm{M}$ phases but increased the percentages of cells in the $\mathrm{S}$ phase. The effect of combined genistein and doxorubicin treatment on cell cycle arrest was much stronger than that of either genistein or doxorubicin alone (Table III and Fig. 3).

Genistein enhances doxorubicin-induced apoptosis. We tested whether genistein enhances doxorubicin-induced apoptosis. Doxorubicin alone did not cause obvious apoptosis in the MCF-7/Adr cells. However, when treated with genistein alone or in combination with doxorubicin, MCF-7/Adr cells became apoptotic $(\mathrm{P}<0.01$; Table IV and Fig. 4). The genistein and doxorubicin combination group showed the highest percentage of apoptotic cells (Table IV and Fig. 4).

Genistein suppresses Her2/neu mRNA expression but not $m d r-1$ mRNA expression. To better understand the molecular mechanism of genistein's effects, we tested the influence of genistein on the expression of mdr-1 and Her2/neu mRNA. Genistein and doxorubicin alone or in combination had no effect on mdr-1 mRNA expression ( $\mathrm{P}>0.05$; Fig. 5A). However, genistein downregulated Her $2 /$ neu mRNA expression in a dose-dependent manner $(\mathrm{P}<0.01$; Fig. $5 \mathrm{~A})$. The combination of genistein and doxorubicin also significantly suppressed Her2/neu mRNA expression ( $\mathrm{P}<0.01$; Fig. $5 \mathrm{~A})$. 


\section{A MCF-7IAdr}

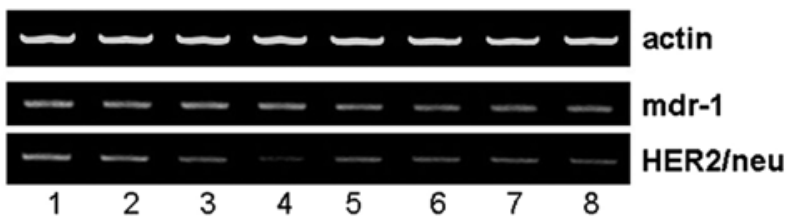

B MCF-7IAdr

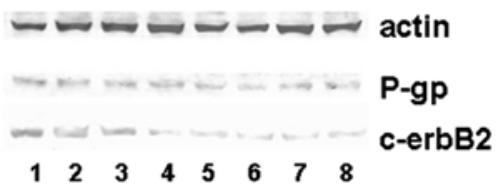

Figure 5. Effect of genistein on Her2/neu, mdr-1, c-erbB2, and P-gp expression. (A) Genistein suppresses mRNA expression of Her2/neu but not mdr-1. Lane 1, control; lane 2, $10 \mu \mathrm{M}$ doxorubicin; lane 3, $1 \mu \mathrm{M}$ doxorubicin; lane 4, $10 \mu \mathrm{M}$ doxorubicin $+60 \mu \mathrm{mol} / 1$ genistein; lane 5,30 $\mu \mathrm{mol} / 1$ genistein; lane 6 , $60 \mu \mathrm{mol} / 1$ genistein; lane 7, $1 \mu \mathrm{mol} / 1$ genistein; lane $8,1 \mu \mathrm{M}$ doxorubicin $+30 \mu \mathrm{mol} / 1$ genistein. (B) Genistein suppresses the protein expression of c-erbB2 but not P-gp. Lane 1, control; lane 2, $10 \mu \mathrm{M}$ doxorubicin; lane 3, $1 \mu \mathrm{M}$ doxorubicin; lane $4,10 \mu \mathrm{M}$ doxorubicin $+60 \mu \mathrm{mol} / 1$ genistein; lane 5 , $30 \mu \mathrm{mol} / 1$ genistein; lane $6,60 \mu \mathrm{mol} / 1$ genistein; lane 7, $1 \mu \mathrm{mol} / 1$ genistein lane $8,1 \mu \mathrm{M}$ doxorubicin $+30 \mu \mathrm{mol} / 1$ genistein.

Genistein suppresses c-erbB2 but not P-gp expression. We examined the expression of P-gp and c-erbB2 proteins. Genistein and doxorubicin alone or in combination had no effect on the expression of P-gp (P>0.05; Fig. 5B). However, genistein downregulated the expression of c-erbB2 $(\mathrm{P}<0.01$; Fig. 5B).

\section{Discussion}

It is well recognized that chemotherapy can significantly improve the prognosis of breast cancer patients; however, the development of multi-drug resistance is the main cause of failure of chemotherapy for long therapeutic durations (23-25). Therefore, reversing and overcoming chemoresistance are urgent and clinically relevant issues that should be resolved by basic research. P-gp-mediated drug resistance is considered a main mechanism by which cancer cells avoid the effects of chemotherapeutic drugs $(26,27)$. Overexpression of the Her $2 /$ neu oncogene has been observed in approximately $30 \%$ of breast cancer patients and is believed to contribute to the failure of chemotherapy (28). Genistein not only inhibits the growth of many types of cancers, but also has a similar structure to drugs that can reverse chemoresistance $(29,30)$. This suggests that genistein may be able to reverse chemoresistance, and indeed, several reports have shown that genistein reverses chemoresistance $(29,30)$. However, the molecular mechanisms of genistein's action are not fully understood. Several mechanisms have been proposed: i) genistein enhances apoptosis by direct inhibition of CYP24 enzyme activity (31); ii) genistein upregulates expression of cell cycle regulators $\mathrm{P} 21^{\mathrm{WAF} / \mathrm{CIPl}}$ and Bax (32); and iii) genistein induces apoptosis via upregulation of PTEN and Bax and enhancement of Bcl-2 and Bcl-XL expression (33). It has been reported that genistein enhances the cytotoxic effect of gefitinib in T790M non-small cell lung cancer cells by inhibiting p-EGFR, p-Akt and p-mTOR expression and promoting caspase-3 and PARP activity (34). Consistent with previous reports, we also found that genistein significantly improved chemotherapeutic efficacy.

Genistein derived from soybeans and other food sources is less expensive than conventional chemotherapeutic drugs. This is significant as most cancer patients are under tremendous economic pressure due to the expensive cost of chemotherapeutic drugs.

Doxorubicin is a first-line chemotherapeutic drug in many cancer types, including breast cancer (35). Therefore, elucidating the molecular mechanisms of chemoresistance and overcoming such resistance are critically important in the clinic. MCF-7/Adr is a well established doxorubicin-resistant cell line and has been widely used to study chemoresistance $(36,37)$. Using MCF-7/Adr cells as a model, we found that genistein greatly increased the intracellular accumulation of doxorubicin, leading to doxorubicin-induced cell death. The intracellular accumulation of doxorubicin was not dependent on P-gp; we did not observe a functional change in $\mathrm{p}-\mathrm{Gp}$ protein using Rhl23, a lipophilic cationic fluorescent dye that can specifically bind to P-gp. This was further confirmed by our RT-PCR and western blot data, which revealed that genistein did not influence the expression of P-gp. These results suggest that genistein increases the intracellular accumulation of doxorubicin by a P-gp-independent mechanism. However, the exact molecular mechanism requires further investigation.

Her2 (also known as Neu) is a member of the epidermal growth factor receptor (EGFR/ErbB) family (38). Thirty percent of breast cancer patients show amplification or overexpression of the Her2/neu gene, and overproduction of this gene contributes to chemoresistance. Overexpression of Her2/neu results in activation of downstream oncogenic pathways, such as the Ras/MAPK and PI3K/Akt pathways. Genistein inhibits receptor tyrosine kinase (RTK) activation and subsequently blocks Her2/neu/PI3K/Akt-mediated chemoresistance (39). Seo et al reported that genistein and quercetin inhibit the growth of MCF-7 human breast cancer cells and MCF-7/Her2 vascular endothelial cell proliferation by inhibition of NF- $\mathrm{KB}$ activation (40). Choi and Kim showed that soy isoflavone aglucones and genistein exhibit anticancer effects by affecting ER $\alpha$ and c-erbB2 receptor expression (41). In addition, genistein was found to strongly inhibit $\mathrm{ER} \alpha$ and c-erbB2 expression in a dose-dependent manner in breast cancer SK-BR 3 and ZR-75 cells. Genistein was found to reduce survivin as well as EGFR, Her2 and ER $\alpha$ expression (42). Consistent with previous reports, we found that genistein suppressed both mRNA and protein expression of c-erbB2. Taken together, these results suggest that genistein overcomes chemoresistance by targeting multiple targets and multiple mechanisms.

The results presented here along with those of previous studies demonstrate that genistein at concentrations of 20-30 $\mu \mathrm{M}$ or greater can significantly inhibit tumor growth. This concentration is far below the $\mathrm{IC}_{50}$ value for cultured bone marrow stromal progenitor cells (CFU-F) and granulocytemacrophage progenitor cells (CFU-GM). This suggests that the drug's toxic effects on the bone marrow are very minimal. Genistein may be a promising multidrug-resistance reversal agent in the clinical treatment of breast cancer. 


\section{Acknowledgements}

This study was supported by the Science Career Development Foundation of Hubei Medical College (2007ZQB14). The authors are grateful to Professor Huang Tao and the Department of Surgery Laboratory of Xiehe Hospital at the Huazhong University of Science and Technology for the valuable technical assistance.

\section{References}

1. Trapé AP and Gonzalez-Angulo AM: Breast cancer and metastasis: on the way toward individualized therapy. Cancer Genomics Proteomics 9: 297-310, 2012.

2. Siegel R, Naishadham D and Jemal A: Cancer statistics, 2013. CA Cancer J Clin 63: 11-30, 2013.

3. Harbeck N: Never too late: reducing late breast cancer relapse risk. Curr Med Res Opin 24: 3295-3305, 2008.

4. Simstein R, Burow M, Parker A, Weldon C and Beckman B: Apoptosis, chemoresistance, and breast cancer: insights from the MCF-7 cell model system. Exp Biol Med 228: 995-1003, 2003.

5. Payne KK and Manjili MH: Adaptive immune responses associated with breast cancer relapse. Arch Immunol Ther Exp 60: 345-350, 2012.

6. Joerger M and Thürlimann B: Chemotherapy regimens in early breast cancer: major controversies and future outlook. Expert Rev Anticancer Ther 13: 165-178, 2013.

7. Redden MH and Fuhrman GM: Neoadjuvant chemotherapy in the treatment of breast cancer. Surg Clin North Am 93: 493-499, 2013.

8. Fuksa L, Micuda S, Grim J, Ryska A and Hornychova H: Predictive biomarkers in breast cancer: their value in neoadjuvant chemotherapy. Cancer Invest 30: 663-678, 2012.

9. Weiss RB: The anthracyclines: will we ever find a better doxorubicin? Semin Oncol 19: 670-686, 1992.

10. Prados J, Melguizo C, Ortiz R, et al: Doxorubicin-loaded nanoparticles: new advances in breast cancer therapy. Anticancer Agents Med Chem 12: 1058-1070, 2012.

11. Brunello A, Roma A, Falci C and Basso U: Chemotherapy and targeted agents for elderly women with advanced breast cancer. Recent Pat Anticancer Drug Discov 3: 187-201, 2008.

12. Alm El-Din MA, El-Badawy SA and Taghian AG: Breast cancer after treatment of Hodgkin's lymphoma: general review. Int J Radiat Oncol Biol Phys 72: 1291-1297, 2008.

13. Khalil MY, Mapa M, Shin HJ and Shin DM: Advances in the management of malignant mesothelioma. Curr Oncol Rep 5: 334-341, 2003

14. Giai M, Biglia N and Sismondi P: Chemoresistance in breast tumors. Eur J Gynaecol Oncol 12: 359-373, 1991.

15. Sakamoto T, Horiguchi H, Oguma E and Kayama F: Effects of diverse dietary phytoestrogens on cell growth, cell cycle and apoptosis in estrogen-receptor-positive breast cancer cells. J Nutr Biochem 21: 856-864, 2010

16. de Lemos ML: Effects of soy phytoestrogens genistein and daidzein on breast cancer growth. Ann Pharmacother 35: 1118-1121, 2001.

17. Usui T: Pharmaceutical prospects of phytoestrogens. Endocr J 53: 7-20, 2006

18. Sarkar FH, Adsule S, Padhye S, Kulkarni S and Li Y: The role of genistein and synthetic derivatives of isoflavone in cancer prevention and therapy. Mini Rev Med Chem 6: 401-407, 2006.

19. Ravindranath $\mathrm{MH}$, Muthugounder S, Presser N and Viswanathan S: Anticancer therapeutic potential of soy isoflavone, genistein. Adv Exp Med Biol 546: 121-165, 2004.

20. Kanagasabai R, Krishnamurthy K, Druhan LJ and Ilangovan G: Forced expression of heat shock protein 27 (Hsp27) reverses P-glycoprotein (ABCB1)-mediated drug efflux and MDR1 gene expression in adriamycin-resistant human breast cancer cells. J Biol Chem 286: 33289-33300, 2011.

21. Lu L, Zhou D, Jiang X, Song K, Li K and Ding W: Loss of E-cadherin in multidrug resistant breast cancer cell line MCF-7/ Adr: possible implication in the enhanced invasive ability. Eur Rev Med Pharmacol Sci 16: 1271-1279, 2012.
22. Zhang HC, Zhang F, Wu B, et al: Identification of the interaction between P-glycoprotein and Anxa2 in multidrug-resistant human breast cancer cells. Cancer Biol Med 9: 99-104, 2012.

23. Gampenrieder SP, Rinnerthaler G and Greil R: Neoadjuvant chemotherapy and targeted therapy in breast cancer: past, present, and future. J Oncol 2013: 732047, 2013.

24. Steward WP and Brown K: Cancer chemoprevention: a rapidly evolving field. Br J Cancer 109: 1-7, 2013.

25. Bartlett J, Canney P, Campbell A, et al: Selecting breast cancer patients for chemotherapy: the opening of the UK OPTIMA trial. Clin Oncol 25: 109-116, 2013.

26. Loo TW and Clarke DM: Location of the rhodamine-binding site in the human multidrug resistance P-glycoprotein. J Biol Chem 277: 44332-44338, 2002.

27. Ruefli AA, Tainton KM, Darcy PK, Smyth MJ and Johnstone RW: P-glycoprotein inhibits caspase- 8 activation but not formation of the death inducing signal complex (disc) following Fas ligation. Cell Death Differ 9: 1266-1272, 2002.

28. Menard S, Pupa SM, Campiglio M and Tagliabue E: Biologic and therapeutic role of HER2 in cancer. Oncogene 22: 6570-6578, 2003.

29. Banerjee S, Li Y, Wang Z and Sarkar FH: Multi-targeted therapy of cancer by genistein. Cancer Lett 269: 226-242, 2008.

30. Tarkowski M, Kokocinska M and Latocha M: Genistein in chemoprevention and treatment. Pol Merkur Lekarski 34: 54-57, 2013 (In Polish).

31. Swami S, Krishnan AV, Peehl DM and Feldman D: Genistein potentiates the growth inhibitory effects of 1,25-dihydroxyvitamin D3 in DU145 human prostate cancer cells: role of the direct inhibition of CYP24 enzyme activity. Mol Cell Endocrinol 241: 49-61, 2005.

32. Yu Z, Tang Y, Hu D and Li J: Inhibitory effect of genistein on mouse colon cancer MC-26 cells involved TGF-beta1/Smad pathway. Biochem Biophys Res Commun 333: 827-832, 2005.

33. Pabona JM, Dave B, Su Y, et al: The soybean peptide lunasin promotes apoptosis of mammary epithelial cells via induction of tumor suppressor PTEN: similarities and distinct actions from soy isoflavone genistein. Genes Nutr 8: 79-90, 2013.

34. Zhu H, Cheng H, Ren Y, Liu ZG, Zhang YF and De Luo B: Synergistic inhibitory effects by the combination of gefitinib and genistein on NSCLC with acquired drug-resistance in vitro and in vivo. Mol Biol Rep 39: 4971-4979, 2012.

35. Tacar O, Sriamornsak P and Dass CR: Doxorubicin: an update on anticancer molecular action, toxicity and novel drug delivery systems. J Pharm Pharmacol 65: 157-170, 2013.

36. Liu Y, Du F, Chen W, Yao M, Lv K and Fu P: Knockdown of dual specificity phosphatase 4 enhances the chemosensitivity of MCF-7 and MCF-7/ADR breast cancer cells to doxorubicin. Exp Cell Res 319: 3140-3149, 2013.

37. Shi R, Peng H, Yuan X, et al: Down-regulation of c-fos by shRNA sensitizes adriamycin-resistant MCF-7/ADR cells to chemotherapeutic agents via P-glycoprotein inhibition and apoptosis augmentation. J Cell Biochem 114: 1890-1900, 2013.

38. Coussens L, Yang-Feng TL, Liao YC, et al: Tyrosine kinase receptor with extensive homology to EGF receptor shares chromosomal location with neu oncogene. Science 230: 1132-1139, 1985.

39. Harari D and Yarden Y: Molecular mechanisms underlying ErbB2/HER2 action in breast cancer. Oncogene 19: 6102-6114, 2000.

40. Seo HS, Choi HS, Choi HS, et al: Phytoestrogens induce apoptosis via extrinsic pathway, inhibiting nuclear factor-kappaB signaling in HER2-overexpressing breast cancer cells. Anticancer Res 31: 3301-3313, 2011.

41. Choi EJ and Kim GH: Antiproliferative activity of daidzein and genistein may be related to ER $\alpha / \mathrm{c}$-erbB-2 expression in human breast cancer cells. Mol Med Rep 7: 781-784, 2013.

42. Mai Z, Blackburn GL and Zhou JR: Genistein sensitizes inhibitory effect of tamoxifen on the growth of estrogen receptorpositive and HER2-overexpressing human breast cancer cells. Mol Carcinog 46: 534-542, 2007. 